\title{
KOMODIFIKASI JILBAB DALAM SEJARAH PERADABAN MANUSIA
}

\author{
Leny Marinda \\ Lembaga Pembinaan Dan Pengembangan Keluarga Sakinah (LPPKS) \\ lenymarindasip@gmail.com
}

\begin{abstract}
Hijab or khimar which is interpreted as a head covering for Muslim women is an interesting theme to be discussed. It is not something new when Islam was born. The discussion has crossed various levels in the history of human life from time to time. Hijab and khimar explained clearly in Al Abrab: 59 and An Nur: 31. The context of the descent of the verses is related to the social, cultural, economic and security of the Muslim community. The development of interpretations of religious, social and cultural texts bring diverse views about Hijab. Now, the hijab, with all its dynamics, has an important position in Muslim life that deserves attention.
\end{abstract}

\section{Keywords: Commodification, Hijab, History of Human Civilization}

\section{Abstrak}

Hijab atau khimar yang diartikan sebagai penutup kepala bagi wanita muslimah menjadi tema yang menarik untuk dibahas. Bukan hal baru ketika Islam lahir. Pembahasan telah melintasi berbagai tingkatan dalam sejarah kehidupan manusia dari masa ke masa. Hijab dan khimar dijelaskan secara gamblang dalam Al Ahzab: 59 dan An Nur: 31. Konteks turunnya ayat tersebut terkait dengan sosial, budaya, ekonomi dan keamanan umat Islam. Perkembangan tafsir teks agama, sosial dan budaya membawa pandangan yang beragam tentang hijab. Kini, hijab dengan segala dinamikanya memiliki posisi penting dalam kehidupan muslim yang patut mendapat perhatian.

\section{Kata Kunci : Komodifikasi, Jilbab, Sejarah Peradaban Manusia}

\section{Pendahuluan}

Jilbab merupakan ragam pakaian yang diidentikkan kepada kaum muslimah. Jilbab juga menjadi isu penting yang didiskusikan kalangan ulama, kaum intelektual 
Vol. 12, No. 2, Oktober 2019

p-ISSN:2086 -0749

e-ISSN:2654-4784

maupun orang awam. Hal ini karena jilbab telah menjadi bagian tak terpisahkan dari model berpakaian muslimah masa kini. Jika yang diperbincangan adalah Jilbab (vei) untuk menutup kepala bagi perempuan, maka bisa kita lacak bahwa itu bukanlah hal yang pure berasal dari agama Islam. Jilbab telah menjadi diskursus dalam Code Bilalama (3000 SM), kemudian berlanjut di Code Hammurabi (2000 SM) dan Code Asyiria (1500 SM). ${ }^{1}$ Ketentuan penggunaan jilbab telah di kenal di beberapa kota tua seperti Mesopotamia, Babilonia dan Asyiria, yang mana periodesasi peradaban kotakota tersebut jauh ada sebelum Islam (Islam lahir sekitar $610 \mathrm{M}$ ).

Tradisi memakai jilbab yang dilakukan oleh masyarakat praIslam, sangat berkaitan dengan pandangan dan sikap mereka ten-

1 Nasarudin Umar, Mendekati Tuhan Dengan Kualitas Feminis, Jakarta: Quanta, 2014) 37 tang menstruasi yang dialami oleh kaum perempuan. Ajaran dan tradisi agama Yahudi terhadap menstruasi sangat tegas. Mereka membatasi interaksi fisik antara perempuan yang sedang mengalami masa mesntruasi dengan keluarga maupun suaminya. Sebagai mana yang tertuang dalam taurat: "when a woman has flow of blood, where blood flowsfrom her body she shall be niddah for seven days"

"bilama seorang perempuan sedang menstruasi ketika darah mengucur dari tubuhnya, maka ia wajib melakukan pemisahan diri (niddah) selama tujuh hari”.

Dalam ajaran agama Yahudi, seorang perempuan yang sedang berada dalam keadaan mestruasi dianggap kotor. Keadaan tersebut membuat ia diharuskan memisahkan diri dari pergaulan dengan masyarakat di sekitarnya, apalagi untuk mendatangi acara 


\section{Leny Marinda}

persembahyangan. Ia baru akan dianggap bersih ketika telah melalui upaca pembersihan diri melalui pencemplungan diri ke dalam air sakral yang disebut "mikveh". 2

Setelah upacara mikveh, barulah para perempuan yang selesai masa menstruasinya, boleh bergaul kembali dengan suami, keluarga dan masyarakat luas. Sehingga setiap bulan, setiap keluarga pasti melakukan upaca mikveh ini. oleh karena itu, terdapat istilah yang muncul dalam tradisi agama Yahudi:

"mikveh adalah bagaikan bulan madu setiap bulan" (mikveh is like a honeymoon in every month). Karena seluruh anggota keluarga akan

${ }^{2}$ Mikveh adalah tradisi pembersihan diri setelah tujuh hari masa menstruasi. Ritual ini dilakukan dengan acara mandi dengan air yang telah diberkahi. Untuk melakukan ritual ini, disediakan tempat khusus yang luasnya sekitar 5x8 kaki dan kedalaman air sekitar 3-4 kaki. Air di dalamnya tidak kurang 40 seah. Suasana yang dibangun disana dirancang sesakraml mungkin. Karena memang diperuntukkan untuk ritual khusus. jika kita cermati, ketentuan bersuci setelah masa haid, tidak hanya di kenal dalam agama islam saja. agama ter-dahulunyapun telah mengenal tradisi bersuci tersebut. berkumpul kembali dalam suasana yang akrab. Namun begitu masa haid/menstruasi itu da-tang, keakraban itu lenyap seketika. Karena sang istri/ibu/anak perempuannya akan kembali diasingkan dan dijauhkan dari keluarganya.

Kesinisan Yahudi terhadap menstruasi ini merupakan persoalan yang prinsipil. Agama Yahudi dan Kristen menganggap bahwa menstruasi yang dialami oleh kaum perempuan merupakan manifestasi kutukan Tuhan (devine creation) terhadap Hawa yang telah melakukan tindakan melanggar ketentuan Tuhan di surga.

Dalam keyakinan kedua agama tersebut, bahwa setelah $\mathrm{Ha}$ wa melakukan suatu tindakan pelanggaran, Adam dan Hawa diusir dari surga dalam keadaan terpisah. Sebelum diturukan ke bumi, Tuhan terlebih dahulu mengambil air sebagai unsur utama kehidupan, yang diambilkan dari empat sungai di surga. Air tersebut, yang dikenal dengan istilah "air ke- 
Vol. 12, No. 2, Oktober 2019

p-ISSN:2086 -0749

e-ISSN:2654-4784

hidupan" (living waters). Itulah yang dalam perkembangan peradaban manusia, menjadi dasar tradisi acara mikveh. Ritual yang diadakan setelah masa tujuh hari pengasingan yang dialami oleh perempuan yang haid tersebut, berupa membersihkan diri dengan cara tertentu seperi mandi dan merapikan rambut.

Selanjutnya, kalangan antropolog berpendapat, bahwa yang menjadi latar belakang pemakaian kerudung (jilbab) dan cadar adalah pandangan tentang menstrual taboo (menstruasi) ini. menurut Epstein, cadar telah dikenal oleh suku bangsa jauh sebelum kitab Taurat diturunkan. Dalam hukum kekeluargaan Asyiria (asyirian code) sudah ditemukan tentang peraturan penggunan kerudung/ cadar bagi kaum perempuan.

"that tradition that women veil themselves when they go out in public is very old in the orient. Probably the first reference is to be found in the assyirian code, where it is roled that wives, danghters, widows, when going to public, must be veiled" "tradisi penggunaan kerudung ke tempat-tempat umum sudah terjadi sejak dahulu kala di timur. Kemungkinan referensi paling pertama ditemukan di dalam hokum asyiria yang mengatur bahwa : istri, anak perempuan, janda, bilamana mau keluar ke tempat-tempat umum harus menggunakan kerudung".

Menurut para antropolog, penggunaan kerudung dan cadar ini bukanlah berasal dari ajaran agama, melainkan dari sebuah kepercayaan bahwa "si mata iblis" (the evil eye) harus dicegah aksinya melalui pemakaian cadar. Penggunaan cadar/kerudung (bood) pertama kali dikenal pemakaiannya oleh kaum perempuan yang sedang memasuki fase menstruasi supaya terhindar dari sinar matahari dan bulan. Sinar 


\section{Leny Marinda}

keduanya dipercaya berbahaya dan dapat menimbulkan terjadinya bencana alam maupun sosial.

Penggunaan kerudung/cadar ini juga merupakan bentuk "tebusan" (pengganti) dari kewajibab pengasingan ketika haid, yang boleh dilakukan oleh para perempuan dari kalangan raja dan bangsawan. Jadi para perempuan dari kalangan tersebut tidak harus diasingkan dan dipisahkan dari keluarga dan masyarakatnya. Cukup memakai pakaian khusus yang menutupi anggota badanyang dianggap sensitive. Jadi, dahulu kala yang menggunakan cadar sudah jelas hanya perempuan dari keluarga kerajaan dan bangsawan saja.

Modifikasi menstrual but menjadi cadar (menstrual hood) juga dilakukan di New Guinea, British Columbia, Asia dan Afrika bagian Tengah, Amerika bagian Tengah dan lain sebagainya. cadar juga pernah dipopulerkan oleh salah seorang keluarga ratu di kepulauan Charlotte.
Selain menggunakan cadar, perempuan haid juga menggunakan zat pewarna hitam (cilla) di daerah sekitar mata untuk mengurangi ketajaman penglihatan mata. Adapula yang menambahkan perhiasan dengan kalung yang dibuat dari bahan logam, manik-manik dan bahan dari tengkorak manusia.

Ketika terjadi peperangan antara Romawi-Byzantium dan Persia berkecamuk, rute perdagangan antar pulau mengalami perubahan untuk menghindari akibat buruk dari perang tersebut. Di beberapa pesisir jazirah Arab tiba-tiba menjadi kota-kota penting tempat persinggahan para pedagang. Wilayah tersebut juga menjadi alternative pengungsian dari daerah yang sedang terlibat pertikaian. Dengan demikian, ada interaksi yang terjadi anatara para pedagang dan pengungsi ini dengan penduduk asli jazirah Arab. Interaksi tersebut tidak hanya secara fisik, tetapi juga tradisi dan budaya juga, termasuk jilbab. 
Vol. 12, No. 2, Oktober 2019

p-ISSN:2086 -0749

e-ISSN:2654-4784

Jilbab yang mulanya merupakan tradisi Mesopotamia-Persia dan pemisahan laki-laki dan perempuan merupakan tradisi hellenistikbizantium, menyebar menembus batas-batas wilayah geografis dan budaya, tidak terkecuali bagian utara dan timur Jazirah Arab. Damaskus dan Baghdad yang pernah menjadi pusat pemerintahan umat Islam, masa dinasti umayyah dan abasiyah, juga tak luput dari senTuhan kultur ini. persinggungan antara peradaban hellenisme-persia dan Islam di dua kota tersebut menjadikan tradisi jilbab dan pemisahan antara laki-laki dan perempuan semakin mempunyai dasar agamis. Dua kota tersebut juga memegang andil besar dalam kodifikasi kitab-kitab standar hadis, tafsir, tarikh dalam agama Islam. Sehingga rasa dari budaya peradaban tersebut juga mempengaruhi perkembangan diskusi agama dan keilmuan pada periode tersebut. ${ }^{3}$

Ketika melihat catatan sejarah di atas, maka dapat diketahui bahwa diskursus tentang kerudung, jilbab, cadar bukanlah merupakan tema baru dalam Islam. Agama Yahudi dan Kristen, sebagai agama yang lahir dan berkembang sebelum Islam, telah mengenal tradisi pemakaian kain penutup kepala tersebut.

Institusionalisasi Jilbab Melalui Ayat: QS. Al Ahzab 59 dan Qs. An Nur 31

Setelah fase Islamisasi jazirah Arab, yang ditandai dengan masa kenabian Muhammad SAW, tradisi berjilbab mengalami formalisasi. Berbeda dengan diskursus jilbab dalam dua agama pendahulunya, Yahudi dan Kristen, dalam islam jilbab tidak dikaitkan dengan men-

${ }^{3}$ Baca buku Hasan Ibrahim Hasan, Sejarah dan Kebudayaan Islam, (Jakarta: Kalam Mulia, 2002) 


\section{Leny Marinda}

strual taboo. Ayat-ayat jilbab dan hijab berbicara tentang konteks budaya, etika, hukum dan keamanan dimana dan kapan ayat itu diturunkan.

Seperti yang diketahui, $\mathrm{Al}$ Quran, sebagai kitab suci agama Islam, secara spesifik membicarakan jilbab dalam QS. Al Ahzab ayat 59 dan QS. An Nur ayat 31. Sebagaimana yang kita ketahui, ayatayat jilbab dan ayat yang umumnya berbicara tentang perempuan, turun dalam rentang waktu ketiga sampai ke tujuh hijriah. tahun-tahun itu merupakan masa kritis bagi komunitas muslim di Madinah. Baru saja terjadi perang Uhud dan umat Islam mengalami kekalahan, lalu disusul dengan beberapa peperangan sporadic lainnya. situasi di Madinah menjadi tidak aman akibat perang yang berkepanjangan.

Dalam situasi yang demikian, ayat-ayat yang berbicara tentang perempuan turun. Ada dua istilah yang popular digunakan oleh $\mathrm{Al}$ Quran untuk menyebut kain pe- nutup kepala, yaitu khumur dan jalabib. Kata khumur (QS. An Nur: 31) merupakan jamak dari kbimar, sedangkan kata jalabib merupakan bentuk jamak dari jilbab (QS. Al Ahzab: 59). Secara tekstual, $\mathrm{Al}$ quran tidak pernah menyebut secara rinci bentuk pakaian khusus sebagai penutup kepala secara pasti. Apalagi, ayat-ayat tentang penutup kepala juga tidak ada yang menyngkut pautkan dengan mitologi dan kelas sosial. Ke dua ayat tentang penutup kepala di atas, menegaskan fungsi penutup kepala bagi para perempuan mukmin masa itu. Ayat jilbab (QS. Al Ahzab) adalah ayat yang turun berkenaan dengan perilaku tidak menyenangkan yang diterima oleh istri nabi ketika buang hajat di malam hari. Dahulu, masayarakat di Arab membuah hajat mereka di luar rumah (padang pasir). Gangguan tersebut dilakukan oleh para lelaki dari kaum munafik. karena malam, para pria tersebut tidak tahu jika yang digoda adalah perempuan merdeka. 
Vol. 12, No. 2, Oktober 2019

p-ISSN:2086 -0749

e-ISSN:2654-4784

keterangan ini adalah uraian tentang sebab turunya ayat Khimar sebagaimana yang disampaikan enam ulama yaitu Ibnu Mundzir, Said bin Manshur, Abd bin Humaid, Saad, dan Ibnu Abi Hatim.

Sebelum ayat jilbab turun, tidak ada perbedaan pakaian yang dikenakan oleh perempuan budak maupun perempuan merdeka. oleh karena itu, lelaki usil seringkali mengganggu wanita-wanita yang diketahui sebagai atau diduga sebagai hamba sahaya/budak. ${ }^{4}$ ayat jilbab turun untuk menegaskan penggunaan tutup kepala yang terulur hingga dada sebagai indicator pembeda antara perempuan merdeka dan budak. Perlu diketahui, pada saat itu, masih

${ }^{4}$ Quraish Shihab, Tafsir Al Misbah Jilid 10, Jakarta: Lentera Hati, 2012. 533. Dalam kitab tafsir ini, Quraish Shihab juga menyinggung penjelasan bahwa QS. Al Ahzab ayat 59 turun untuk keperluan penghormatan terhadap kaum perempuan merdeka, suapaya ada pembeda antara wanita merdeka dan budak sahaya. dikenal adanya perbedaan kelas sosial antara merdeka dan budak. Kaum budak sebagai kasta terendah dalam kelas sosial bangsa arab, kerap mendapat perlakuan merendahkan dari kaum merdeka. oleh karena itu, jelas bahwasanya yang menjadi alasan pemakaian jilbab pada saat itu adalah fungsinya, yaitu pembeda antara budak dan perempuan merdeka.

Masih dari kitab tafsir al misbah, kata jilbab pada ayat 59 surat Al Ahzab diperselisishkan maknanya oleh ulama. Al Biqa'I menyebutkan beberapa pendapat. Antara lain yaitu baju yang longgar atau kerudung penutup kepala wanita, atau semua pakaian yang menutupi wanita. Menurutnya, kesemuanya merujuk pada makna kata jilbab. Jika yang dimaksud jilbab adalah baju, maka ia menutupi tangan dan kakinya. Jika yang ditujua adalah kerudung, maka perintah men- 


\section{Leny Marinda}

gulurkan adalah untuk menutupi wajah dan lehernya. Jika yang dimaksud ayat tersebut adalah pakaian yang menutupi baju, maka mengulurkan bermakna membuatnya longgar agar menutupi semua badan dan pakaian. ${ }^{5}$ Sedangkan Thabathaba’i memaknai jilbab sebagai pakaian yang menutupi seluruh badan atau kerudung yang menutupi kepala dan wajah.

Berbeda dengan pendapat diatas, Ibn Asyur memberikan deskripsi tentang jilbab sebagai pakaian yang lebih kecil dari jubbah namun lebih besar dari kerudung atau penutup wajah. Kain ini diletakkan wanita di atas kepala dan terulur melalui kedua pipi hingga ke seluruh bahu dan belakangnya. ${ }^{6} \mathrm{Ibn}$ Asyur memberikan tambahan penjelasan bahwa model jilbab bisa sangat beragam tergantung selera wanita yang memakai dan adat istiadat serta budaya yang ada di dae-

${ }^{5}$ Quraish Shihab, Tafsir Al Misbah Ji-lid 10, h. 533

${ }^{6}$ Quraish Shihab, Tafsir Al Misbah Ji-lid 10, h. 534 rah tersebut. karena yang menjadi titik tekan dari kosep berjilbab dalam ayat ini adalah fungsinya “...menjadikan mereka lebih mudah dikenal sehingga tidak diganggu"?

Menurut Al-'Asymawi dan $\mathrm{Mu}$ hammad Syahrur, terkait dengan alasan dan motivasi tertentu (illat),

${ }^{7}$ Kalau kita lihat di sini, ketimbang terjebak dengan batasan bagian mana yang harus ditutup atau terkena dampak aktifitas "mengulurkan" yang dimaksud dalam QS. Al Ahzab ayat 59 ini, Ibn Asyur lebih menitik beratkan maksud dari berjilbab dalam ayat tersebut adalah fungsi dari jilbab itu sendiri. Oleh karena itu, beliau berpendapat akhir dari ayat tersebut yang berbunyi tentang keberadaan "Allah yang Maha pengampun lagi Maha Penyayang" adalah ditujukan kepada wanita mukminah yang pada saat itu belum mengulurkan jilbabnya atau wanita masa kini yang pernah terbuka auratnya dan segera bertaubat dengan memakai jilbab atau menutupnya. Pengampunan Allah adalah untuk mereka yang menyadari kesalahannya dan mau berusaha sekuat tenaga untuk memperbaikinya. Demikian yang disampaikan oleh Ibn Asyur sebagaimana yang dituliskan Quraish Shihab dalam Tafsir Al Misbah.

Sebagai ulama yang diakui otoritasnya tentang ilmu agama, Ibn Asyur yang berasal dari Tunisia ini mengungkapkan dalam bukunya yang berjudul Maqasid $A l$ Syariah "kami percaya bahwa adat atau kebiasaan suatu kaum tidak boleh kedudukannya sebagai adat- untuk dipaksakan kepada kaum lain atas nama agama, bahkan tidak pula dipaksakan kepada kaum itu" 
Vol. 12, No. 2, Oktober 2019

p-ISSN:2086 -0749

e-ISSN:2654-4784

karenanya berlaku kaidah "suatu hokum terkait dengan illat". Dimana ada illat disitu ada hokum. Jika illat hilang, bergeser, berubah, maka hokum yang menjadi akibat dari adanya illat tersebut juga mengalami perubahan. ${ }^{8}$

Karena tidak menyinggung redaksi yang gamblang terkait penutup kepala, maka kedua ayat di atas berimplikasi kepada perbedaan penafsiran di kalangan ulama ushul fikih, apakah yang menjadi dasar hokum itu sebab turunnya yang secara khsusus atau redaksi ayat yang bersifat umum. Ketika kedua pendapat ini diterapkan, maka implikasi hokum yang muncul juga akan berbeda.

Sedangkan hadist yang berbicara tentang jilbab adalah hadis ahad (diriwayatkan oleh perseorangan) yang termonumen dalam sunan abu h. 43 daud. Hadis yang diriwayatkan oleh 'Aisyah ini berbunyi "tidak diperkenankan seorang perempuan yang beriman kepada Allah dan Rasul Nya jikea sudah sampai usia baligh menampakkan (anggota badannya) selain muka dan kedua tangannya sampai di sini, sambil menunjukkan setengah hasta". Hadis lain, masih dengan kualitas ahad, yang diriwayatkan oleh Aisyah adalah menceritakan tentang Asma Binti Abu Bakar yang masuk ke dalam rumahnya, kemudian rasulullah berkata "wahai asma, sesunggubnya perempuan jika sampai usia baligh, tidak. boleh di pandang kecuali yang ini, sambil Rasulullab menunjukekan wajah dan telapak tangannya".

${ }^{9}$ Menurut 'Asymawi, kedua hadis ini merupakan hadis ahad, bukan hadis yang mutawattir atau masyhur. Menggunakan hadis jenis ini sebagai bujjah hokum akan menimbulkan kontroversi. Malah hadis ini ada yang memursalkan ketika bersumber dari Khalid Ibn Darik. Karena dia bukan hanya hanya tidak berjumpa (mu'asharah) tetapi juga tidak bertemu (liqa) dengan 'Aisyah. Lihat dalam Nasarudin Umar, Mendekati Tuban......44 


\section{Leny Marinda}

Kalau sekiranya hadis ini diperuntukkan untuk kalangan muslimah yang luas, maka sejak awal tradisi memakai jilbab di kalangan sahabat dan tabi'in, menurut 'Asymawi lebih merupakan keharusan yang disebabkan oleh budaya, bukan agama. karena tradisi berjilbab merupakan tradisi kolektif keseharian (sunnah muttawatirah bi alfi'l).

Dalam ilmu tafsir, terdapat konteks penafsiran ayat dengan ayat. Berlaku pada QS Al Ahzab ayat 59 tentang jilbab ini adalah ayat tentang Khimar, yaitu QS An Nur ayat 31. Redaksi ayat tersebut adalah "Katakanlah kepada wanita-wanita mukminah 'hendaklah mereka menahan pandangan mereka dan memelibara kemaluan mereka dan janganlah mereka menampakekan hiasan mereka kecuali yang nampak darinya dan bendaklah mereka menutupkan kain kerudung mereka ke dada mereka, dan janganlah mereka menampakkan perbiasan mereka, kecuali kepada suami mereka, atau ayah mereka, atau ayah suami mereka, atan putra-putra mereka, atan putraputra suami mereka, atau saudarasaudara laki-laki mereka, atan anak laki-laki dari saudara-sandara laki-laki mereka, atan putra-putra saudara perempuan mereka atau wanita-wanita mereka atau budak-budak yang mereka milikei, atau pelayan-pelayan laki-laki yang tidak memiliki keinginan, atau anak-anak yang belum mengetabui aurataurat wanita. Dan jangnlah menghentakkan kaki mereka agar diketahui perhiasan yang mereka sembunyikan dan bertaubatlah kamu sekalian kepada Allab, hai orang-orang mukmin supaya kamu beruntung". 10

Pengecualian untuk hal-hal yang diperbolehkan untuk tampak seperti redaksi "kecuali yang tampak. darinya" mengundang berbagai penafsiran dari kalangan ahli tafsir. Ibn 'Athiyyah, sebagaimana yang penjelasannya dikutib dalam tafsir Al Misbah, pengecualian tersebut dapat berkembang sesuai dengan

\footnotetext{
${ }^{10}$ Departemen Agama RI, Al Quran dan Terjemahannya, (Bandung: Syamil Quran, 2009). 353
} 
Vol. 12, No. 2, Oktober 2019

p-ISSN:2086 -0749

e-ISSN:2654-4784

situasi yang mendesak yang dialami seseorang.

Berbeda pandangan dengan Ibn 'Athiyyah, Al Qurthubi menyampaikan bahwa pengertian "kecuali yang tampak darinya" adalah wajah dan telapak tangan sebagaimana yang memang diperlihatkan ketika menjalankan ibadah shalat dan haji. Karena titik tekannya adalah "kebiasaan", maka pertanyaan yang kemudian muncu adalah apakah kebiasaan yang dimaksud dalam ayat ini adalah kebiasaan yang dilakukan oleh wanita pada zaman ketika ayat ini turun, ataukan kontekstual berdasarkan kebiasaan wanita muslim disetiap zaman dan setiap tempat? Hal ini kemudian menjadi bahan diskusi yang asyik di kalangan ulama tafsir.

Masih menutut Al Qurthubi, yang dimaksud "kebiasaan" dalam QS An Nur ayat 31 ini adalah kebiasaan yang ada pada masa turunnya ayat ini. begitu pula ulama Al Mutaqaddimin (terdahulu), bersepakat tentantang batas-batas ditoleransi pakaian wanita. Ketika ayat ini disandingkan dengan $\mathrm{Qs} \mathrm{Al}$ Ahzab ayat 59, seperti yang sudah di singgung sebelumnya, maka konteks kebiasaan dalam berpakaian, khusunya kaum wanita yang menjadi objek kedua ayat ini, maka Ibn Asyur, mengkategorikan "perintah" mengulurkan jilbab adalah berkaitan dengan adat orangorang Arab, sehingga bangsa lain yang tidak menggunakan jilbab tidak memperoleh bagian dalam ketentuan ini. ${ }^{11}$

Quraish Shihab memberikan pernyataan yang hati-hati tentang jilbab bagi kaum muslimah ini. dalam Tafsirnya, beliau menganjurkan untuk bersikap toleran terhadap perbedaan cara memakai jilbab.

\footnotetext{
${ }^{11}$ Quraish Shihab, Tafsir Al Misbah Jilid 8, (Jakarta: Lentera Hati, 2012) 533
} 


\section{Leny Marinda}

Pemakaian jilbab yang menutup seluruh anggota tubuh dengan menyisakan wajah dan telapak tangan, sesuai bunyi teks An Nur ayat 31 sah sah saja. namun disaat yang sama, kita tidak wajar ketika berkomentar bahwa yang tidak memakai kerudung itu sudah pasti melanggar petunjuk agama. karena Al Quran memang tidak menyebut secara gamblang batasan aurat yang harus ditutupi oleh kaum muslimah. ${ }^{12}$ Jilbab sebagai bagian dari pakaian muslimah juga penting untuk memperhatikan prinsip kenyamanan bagi si pemakai, yang itu sangat berkaitan dengan situasi alam dan sosial di mana jilbab akan digunakan. Karena jika kita lihat, konteks ayat tentang jilbab ini adalah kepada fungsinya. Yakni sebagai alat yang membedakan antara wanita terhormat dan budak (QS. Al Ahzab: 59), serta sebagai penutup perhiasan yang dapat membangkitkan hasrat seksual bagi

\footnotetext{
${ }^{12}$ Quraish Shihab, Tafsir Al Misbah Jilid 8 ....534
}

lawan jenisnya (QS.An Nur:31).

Dengan melihat konteks ayat tersebut, pun tidak fair ketika Barat mengatakan bahwa jilbab/kerudung adalah symbol penindasan bagi kaum muslimah.

Persepsi senada juga disampaikan oleh aminah wadud. Dalam pandangannya, perintah mengenakan penutup kepala dalam QS. An Nur ayat 31 adalah karena Islam memberlakukan prinsip kesopanan dan pengakuan terhadap kebiasaan-kebiasaan yang berlaku masa itu. Kerudung dan pingitan bagi perempuan dari suku-suku kaya dan berpengaruh bermaksud memberikan perlindungan. Prinsip kesopanan yang ditampilkan Islam dengan praktik berjilbab adalah dipengaruhi factor sosial, budaya dan ekonomi.

Kesopanan berfungsi menjaga esensi moral dari berbagai bangsa. Oleh karenanya, pemeliharaannya tidak elok jika hanya menggunakan aspek budaya dan ekonomi saja. Aspek keimanan ha- 
Vol. 12, No. 2, Oktober 2019

p-ISSN:2086 -0749

e-ISSN:2654-4784

rus diutamakan. Supaya semua perempuan mukmin yang berjilbab (tanpa melihat suku, golongan, sosial dan ekonomi) dapat memperoleh perlindungan dan keamanan yang adil atas tindakan sopan yang sudah mereka lakukan (berjilbab). ${ }^{13}$

\section{Temuan Penelitian dan}

\section{Pembahasan}

\section{Komodifikasi}

Tradisi

\section{Berjilbab: Dialog Antara Agama}

\section{dan Budaya}

Pembukaan tulisan ini telah menjelaskan bahwasanya tradisi berjilbab bukanlah tradisi pakaian yang pure berasal dari ajaran agama Islam. Peradaban manusia yang hidup jauh sebelum Islam lahir dan berkembang, telah mengenal budaya mengenakan jilbab bagi kaum wanita. Kegunaannyapun berbeda-

\footnotetext{
${ }^{13}$ Amina Wadud, Quran Menurut Perempuan, (Jakarta: Serambi, 2006) 30
}

beda. Jika peradaban MesopotamiaAsyiria mengaitkan penggunaan jilbab dengan menstrual taboo yang penuh dengan makna mistik, maka Islam menggunakan jilbab sebagai “tanda pengenal” bagi kaum wanita merdeka serta sarana menutupi perhiasan atau anggota tubuh yang dimungkin mendatangkan mudharat ketika diperlihatkan.

Selain agama Islam, Yahudi dan Nasrani sebagai agama yang lebih dahulu lahir juga telah mengenal tradisi berjilbab. Seperti yang disampaikan dalam buku yang berjudul The Jewis Woman In Rabbinic Literature yang ditulis oleh seorang pendeta Dr. Menachem M Brayer, seorang professor di bidang Literatue Bible di Universitas Yeshiva, bahwa sudah menjadi kebiasaan bagi wanita yahudi yang keluar rumah atau ketempat umum untuk menggunakan penutup kepala, yang dengannya, kadangkala menutup 


\section{Leny Marinda}

seluruh wajahnya hingga hanya menyisakan sebelah matanya saja. Perempuan yang keluar rumah tanpa menggunakan kepala akan mendatangkan kemiskinan juga menjadi mitos yang berkembang saat itu.

Dr. Brayer juga menuliskan, bagi Yahudi, kerudung yang menutupi kepala perempuan bukan hanya merupakan symbol sopan santun, tetapi juga symbol kehormatan dan juga symbol kemewahan. Kerudung dianggap sebagai lambing kebangsawanan bagi kaum perempuan. Kerudung juga menjadi lambing bahwa perempuan tersebut hanya boleh disentuh oleh sembarang pria, kecuali suaminya saja. ${ }^{14}$

Sedangkan dalam agama Kristen, telah umum kita lihat penampilan para biarawati Katolik. Paulus memberikan dasar pemikirannya bahwa kerudung merupakan lambang wibawa lakilaki, yang merupakan bayangan dan kemuliaan Tuhan, atas wanita yang

\footnotetext{
${ }^{14}$ Suherman rosyidi, Wanita Dalam Doktrin Islam, Yabudi Dan Kristen, (Surabaya: Target Press) 90
}

diciptakan dari dan untuk laki-laki. St. Tertullian dalam "On The Veiling Of Virgins" menulis:"hai para wanita, pakailah kerudung apabila kamu berada di jalan, dan kamu juga harus memakainnya apabila ke Gereja, pakailah ketika kamu berada di tengah-tengah orang yang tidak kamu kenal, pakailah ketika kamu berada di antara saudara lakilakimu...". ${ }^{15}$ Jelas bahwa fungsi kerudung yang dipakai oleh kedua agama ini tidak jauh berbeda dengan Islam, yakni fungsi penghormatan.

Sebagai sebuah budaya, jilbab telah berevolusi menjadi sebuah doktrin/ajaran yang terlembagakan dalam agama. ketika, ajaran ini berangkat dari budaya, maka konteks ajaran inipun mengalami perluasan seiring dengan perkembangan kebudayaan dan peradaban manusia. Seperti yang disampaikan oleh KH. Husein Muhammad, seorang ulama yang concern terhadap

\footnotetext{
${ }^{15}$ Suherman rosyidi, Wanita Dalam Doktrin Islam, 93-94
} 
Vol. 12, No. 2, Oktober 2019

p-ISSN:2086 -0749

e-ISSN:2654-4784

isu-isu gender, dalam bukunya Islam Agama Ramah Perempuan, bahwa perintah berjilbab dalam islam sangat bergantung kepada budaya kapan dan dimana ayat tentang jilbab itu turun.

Sebagaimana yang telah kita bahas sebelumnya, ayat yang memerintahkan untuk menggunakan jilbab turun ketika bangsa Arab masih mengenal adanya budak. Jilbab diperintahkan untuk dipakai guna membedakan antara pakaian wanita merdeka (terhormat) dengan wanita dari kalangan budak, yang pada saat itu memang diperlakukan tidak sama dengan orang merdeka. kini perbudakan telah dihapuskan. Oleh karena alasan (illat) dari perintah tersebut sudah tidak ada, maka keharusan mengulurkan jilbab sebagaimana yang dibunyikan dalam QS. Al Ahzab ayat 59 menjadi kehilangan konteks hokum. ${ }^{16} \mathrm{Wa}-$ laupun penggunaannyapun tidak dilarang.

Kini, bisa kita lihat bersama, tren berjilbab telah menjangkau berbagai kalangan muslimah. jilbab tidak lagi dipakai oleh kalangan atas saja. guru, officer, hingga kalangan buruh bebas menggunakan jilbab. Jilbab tidak lagi menjadi icon kelas sosial dalam masyarakat saat ini. Bahkan, bisa kita lihat bersama banyak kalangan selebritis dan public figure yang turut serta mengkampanyekan budaya berjilbab. Entah itu yang berangkat dari refleksi ketauhidan (mereka biasa menyebut dengan istilah "hijrah") maupun untuk kebutuhan endorse (iklan) untuk menekan laju industrialisasi dan konsumerisme masyarakat luas dalam menggunakan jilbab. Muslimah di Indonesia dapat membeli jilbab

\footnotetext{
${ }^{16}$ Husein Muhammad, Islam Agama Ramah Perempuan, (Yogyakarta: LKiS, 2009) 216
} 


\section{Leny Marinda}

mulai dari harga kaki lima hingga "bintang lima", karena ragam harga dan bahan yang digunakan semakin variatif.

Tumbuh suburnya indutri untuk produksi dan penjualan jilbab serta busana muslimah tidak lepas dari tren maraknya segala sesuatu yang mendapat predikat halal. Jilbab, pakaian muslimah sebagai representasi pakaian halal bagi muslimah, turut serta memberikan sumbangsih dalam menaikkan kesadaran akan konsep "halal" dalam kehidupan sehari-hari. Indikatornya adalah, masuknya jilbab dan busana muslimah ke dalam ajang fashion show hingga award sebagai media kampanye jilbab.

Merespon pasar seperti di atas, Pasar untuk kebutuhan gaya hidup Muslim memang menarik. Dalam laporan yang dibuat Reuters bekerja sama dengan DinarStandard, "State of the Global Islamic Economy Report", konsumen Muslim menghabiskan kurang lebih 243 miliar dolar AS untuk pakaian di tahun 2015. Khusus untuk busana Muslim saja angkanya tahun itu mencapai 44 miliar dolar, atau 18 persen dari keseluruhan. Dikutip dari Forbes, angka belanja Muslim untuk pakaian diprediksi akan mencapai 268 miliar dolar AS di tahun 2021. Atau meningkat 51 persen dari tahun 2015. ${ }^{17}$ Peningkatan ini bisa kita duga, mungkin dikarenakan konsepsi "hijrah" dengan "membumikan" ayat-ayat jilbab, karena meningkatnya semangat imitasi gaya berpakaian ala Timur Tengah atau trend mode berpakaian yang praktis dan Islami.

Terlepas dari sekian praduga yang muncul, fenomena yang layak kita sorot adalah proses transformasi fungsi jilbab serta citra yang menyertainya. Jilbab hari ini merupakan bagian dari komoditas (agama, sosial dan budaya). Jilbab hari ini dipandang sebagai bagian dari indikator untuk menilai keislaman dan ke "hijrah"an seseorang, tanpa menilik motivasi dan dasar ia

\footnotetext{
${ }^{17}$ www.republika.co.id
} 
Vol. 12, No. 2, Oktober 2019

p-ISSN:2086 -0749

e-ISSN:2654-4784

menggunakan jilbab. Pandangan menggolongkan jilbab sebagai komoditas pasar dan sosial juga terlihat dengan banjirnya pasar mode dengan aneka jilbab berbagai model dan harga, yang mempengaruhi konsumen dan pemakainya. Transformasi fungsi jilbab, mulai dari awal kemunculnannya hingga saat ini, menjadi satu hal yang menarik untuk diperbincangkan. Jilbab (penutup kepala) yang tadinya produk budaya masyarakat, bertransformasi dan berdialog dengan agama pemakainya. Konsep peralihan fungsi suatu komoditas inilah yang dimaksud dengan komodifikasi dalam makalah ini.

Secara terminologi, komodifikasi adalah proses transformasi barang dan jasa yang semula dinilai karena nilai gunanya menjadi komoditas yang bernilai karena ia bisa mendatangkan keuntungan di pasar. ${ }^{18}$ Komodifikasi berjilbab dimaknai sebagai perluasan niat dan minat berjilbab dari masa ke masa. Komodifikasi fungsi dari yang tadinya digunakan sebagai ikhtiar penggati "rumah pengasingan" bagi perempuan bangsawan yang sedang menjalani masa periodenya, aksesoris bernilai sosial, alat pembeda antara wanita merdeka dan budak, penutup hiasan tubuh wanita hingga komoditas pasar mode yang menggiurkan.

Selain potensi fungsi yang telah disebutkan diatas, jilbab juga tampil sebagai sebuah kekuatan, pergerakan, pertahanan dan proteksi. Pada tahun 1970-an, di Iran kekuatan gerakan Mullah mencapai puncaknya. Hal ini ditandai dengan keberhasilan Imam Khomaeni menggusur kekuasaan

\footnotetext{
${ }^{18}$ Idi Subandy dan Bacharuddin Ali Akhmad, Komunikasi Dan Komodifikasi, (Jakarta: Yayasan Pustaka Obor Indonesia, 2014) 17
} 


\section{Leny Marinda}

Reza Pahlevi yang disinyalir menjadi antek dunia Barat di Timur-Tengah. Maka kemenangan Khomaeni ini dipopulerkan sebagai kemenangan Islam atas boneka Barat. Symbolsimbol kekuatan Khomaeni, seperti foto Imam Khomaeni dan komunitas black veil menjadi trend di kalangan generasi muda Islam di seluruh dunia. Sejak saat itu, jilbab menghiasi kampus-kampus dunia Islam, tidak terkecuali di Indonesia. Identitas jilbab seolah-olah menandakan kemenangan.

Dalam perkembangannya, pasca perang dingin blok timur dan blok barat usai, berbanding lurus dengan pesatnya perkembangan tekhnologi dan informasi, maka timbulm kekhawatiran dan kecemasan umat islam, terutama kelangsungan generasi mudanya. Islam dan segala simbolnya berhadapan dengan Dunia Barat. Tesis yang dikemukakan oleh Huntington juga mendukung terhadap kecemasan yang dirasakan umat Islam saat itu.

Setelah Uni Soviet bubar, maka benturan vis a vis baru yang muncul adalah Timur-Islam dan BaratKristen. Tendensi ini diperkuat dengan insiden 11 september di WTC, bom Bali, bom Madrid atau bom London.

Jilbab menjadi alat proteksi westernisasi dan dalam skala tertentu juga hadir sebagai perlawanan terhadap ancaman deislamisasi. Jika potensi yang terakhir dominan, maka sangat riskan jilbab dipolitisasi dengan memanfaatkan emosi dibalik tradisi berjilbab. ${ }^{19}$ Negara Perancis yang dengan tegas memproklamirkan dirinya sebagai Negara sekuler dan menjunjung tinggi asas pluralisme, mengeluarkan larangan kepada masyarakatnya menggunakan symbol-simbol keagamaan (jilbab bagi orang Islam dan Peci bagi orang Yahudi) di tempat-tempat umum. Hal ini untuk menghindari konflik horizontal yang terjadi akibat perbedaan symbol keagamaan yang diper-

\footnotetext{
${ }^{19}$ Nasaruddin Umar, Fikih Wanita Untuk Semua, (Jakarta: Serambi, 2010) 36-37
} 
tontonkan. Bahkan sekolah tidak segan-segan untuk mengeluarkan siswa yang tetap menggunakan jilbab. Kebijakan ini tentu memancing reaksi keras dari para agamawan. Jilbab dan peci bagi kedua agama tersebut bukan hanya sekedar aksesoris pakaian saja, tetapi juga bentuk ketaatan mereka terhadap ajaran agama yang dianutnya.

Kebijakan pelarangan seperti ini, disamping dianggap sebagai tindakan mengebiri hak-hak beragama seseorang, juga semakin membangkitkan militansi tiap-tiap pemeluk agama terhadap aksi sekulerisasi. Kedamaian semakin sulit dicapai ketika masing-masing pemeluk agama yang berlainan saling curiga dan waspada akan ancaman pihakpihak di luar keyakinan agamanya. ${ }^{20}$

\footnotetext{
${ }^{20}$ Sebagaimana yang diceritakan oleh Bikhu Parekh, kebijakan pelarangan berjilbab berawal dari kejadian tiga siswa muslim yang mengenakan jilbab pada saat sekolah di Perancis September 1989. Kebetulan saat itu adalah hari Sabbath.
}

Terakhir, tulisan reflektif ini ingin mengajak pembaca untuk ber-

Kemudian 20 siswa yahudi yang sekelas dengan siswa berjilbab tersebut menolak untuk memasuki kelas. selanjutnya, sekolah memberikan kebijakan pelarangan dengan dasar bahwa hal tersebut bertentangan dengan ketentuan (laicite') sekolah negeri perancis. Sebagai wujud dukungan terhadap 3 siswa berjilbab tersebut, banyak gadis muslim di perancis ramai-ramai mengenakan jilbab ke sekolah, sehingga hal ini mengundang perhatian dari khalayak nasional. Dengan berbagai pertimbangan dan aturan yang ambigu, Dewan mengeluarkan aturan dibolehkannya pemakaian identitas keagamaan. Dengan sekian penolakan yang mengiringinya, akhirnya drama tersebut terpecahkan ketika seorang dari tiga siswa tersebut secara sukarela dan dua lainnya (kabarnya karena tekanan oleh raja Hasan dari Maroko) menurunkan jilbab mereka sampai bahu ketika berada di kelas. hingga akhirnya sepetember 1994, menteri pendidikan Francois Bayrou mengatur bahwa penggunaan symbol-simbol agama yaitu lambing-lambang yang menarik perhatian yang didalamnya mengandung unsur penyebaran agama dan diskriminasi, di larang di Perancis. Lihat selengkapnya dalam Bikhu Parekh, Thinking Multiculturalism: Keberagaman Budaya Dan Teori Politik, Yogyakarta: Kanisius, 2008. 330-336. terjemahan oleh C.B Bambang Kukuh Adi dari Bikhu Parekh, RETHINKING MULTICULTURALISM. Cultural Diversity And Political Theory, 2 nd edition, PALGRAVE MACMILLAN, Hounmills, Basingstoke, Hampshire RG21 6XS and 175 Fifth Avenue, New York 


\section{Leny Marinda}

sikap bijak dalam menyikapi tradisi berjilbab. Bagi mereka yang menggunakan, barangkali sudah mencapai titik pemahaman keagamaan tekstual bahwa mengulurkan jilbab adalah kewajiban bagi muslimah yang telah baligh. Besar harapan mereka mengenakannya atas dasar kesadaran tauhid yang tepat. ${ }^{21}$ Pun begitu pula sebaliknya, bahwa konteks hukum ayat dan hadis tentang kewajiban berjilbab adalah bersandar pada kondisi sosial dan budaya kapan dan dimana dasar hukum tersebut hadir.

Untuk mewujudkan cara pandang di atas, maka kita perlu menggunakan suatu paradigma terbuka dalam memandang Islam, tidak dikotomis. Karena sikap seperti itu hanya akan menjadikan kita ekslusif. Karena bagaimanapun juga, kita perlu terus menyadari bah-

\footnotetext{
${ }^{21}$ Sebagaimana yang disinggung oleh seorang feminis Indonesia, siti musdah mulia dalam pengantar buku Psicology Of Fashion karya juneman yang memaparkan tentang fenomena perempuan melepas jilbab. Lihat dalam Junema, Psicology Of Fashion, Yogyakarta: LKiS, 2012
}

wa kita mewarisi tradisi sejarah dari seluruh warisan sejarah peradaban manusia. Itu artinya, peradaban yang kita bangun hari ini bukan berangkat dari ruang kosong (vacuum). Dalam perjalanannya, sejarah peradaban dan agama mengalami proses take and give satu sama lain. ${ }^{22}$ Sehingga dialog antar keduanya dapat menghantarkan harmoni dan keterbukaan cara pandang beragama. Hal ini juga dapat menjadi tawaran pembaruan dalam beragama. Pembaruan disini bukan bermaksud menghapus doktrin sentral agama, namun bermaksud melakukan reorientasi dan reinterpretasi terhadap pemahaman keagamaan dengan kenyataan empiris yang dihadapi umat manusia, agar agama menjadi hal yang humanis.

\section{Simpulan}

Dalam menyikapi dialog tentang jilbab ini, ada beberapa per-

\footnotetext{
${ }^{22}$ Kuntowijoyo, Islam Sebagai Ilmu (Edisi Kedua), Yogyakarta: Tiara Wacana, 2006
} 
Vol. 12, No. 2, Oktober 2019

p-ISSN:2086 -0749

e-ISSN:2654-4784

sepsi yang dapat kita lakukan. Dengan melihat berbagai perspektif ini, berharap kita bisa bersikap adil dan terbuka terhadap dialektika yang muncul dan berkembang.

Pertama, memandang jilbab sebagaimana apa yang disampaikan oleh QS. Al Ahzab ayat 59 dan An Nur ayat 31 secara tekstual. Tanpa mengindahkan aspek tradisi, nuansa psikologis dan sosial budaya yang ada pada saat kedua ayat tersebut turun. Artinya, menggunakan jilbab dengan jenis, mode dan batasan yang telah ayat-ayat tersebut "ucapkan". Walaupun cendenrung mengarah kepada Arabisasi, namun yang sedemikian ini nyatanya hari ini menjadi trend berbusana muslimah yang kembali mengemuka. Karena dipandang sebagai tuntunan yang outentik dalam berjilbab. Ditunjang dengan gencarnya gerakan bijrah yang menggunakan simbol- simbol Islam-Arab sebagai alat dan metode syiar.

Kedua, adalah melihat jilbab bukan hanya berdasarkan aspek teks kebahasaan yang diucapkan ayat-ayat jilbab, tetapi juga menelaah unsur sosial budaya, politik keamanan serta tradisi masyarakat yang hidup dan berkembang saat itu. Ini mungkin yang kemudian, setidak-tidaknya digunakan oleh sebagian ulama mufassirin kontemporer seperti Quraish Shihab, Ibn As-Syur, serta pegiat gender seperti Amina Wadud Nasaruddin Umar, Musdah Mulia dan tokoh-tokoh lainnya untuk menginterpretasi ayat-ayat jilbab. Mereka juga meletakkan jilbab bukan semata-mata karena dasar wahyu dan hadis saja, namun juga memperhitungkan aspek asababun nu₹ul (sebab turunnya ayat), konteks sosial budaya, aspek politik dan keamanan serta tradisi berpakaian masyarakat 


\section{Leny Marinda}

Arab pada saat itu. Sehingga, harapannya spirit dalam berjilbab benarbenar bukan hanya sebatas sebagai bagian dari kepatuhan hamba terhadap tuntunan Al Quran semata, namun juga bisa dinisbatkan atas unsur "kemanuasiaan" yang memakainya. Wallahu a'lamu bis Shawab

\section{Daftar Pustaka}

Departemen Agama RI, Al Quran dan Terjemahannya, (Bandung: Syamil Quran, 2009)

Ibrahim Hasan, Hasan, Sejarah Dan Kebudayaan Islam, (Jakarta: Kalam Mulia, 2002)

Junema, Psicology Of Fashion, (Yogyakarta: LKiS, 2012)

Kuntowijoyo, Islam Sebagai Ilmu (Edisi Kedua), (Yogyakarta: Tiara Wacana, 2006)

Muhammad, Husein , Islam Agama Ramah Perempuan, (Yogyakarta: LKiS, 2009)

Parekh, Bikhu, Thinking Multiculturalism: Keberagaman Budaya Dan Teori Politik, Yogyakarta: Kanisius, 2008. 330-336. terjemahan oleh C.B Bambang Kukuh Adi dari Bikhu Parekh, Rethinking Multicultur- alism. Cultural Diversity And Political Theory, $2{ }^{\text {nd }}$ edition, PALGRAVE MACMILLAN, Hounmills, Basingstoke, Hampshire RG21 6XS and 175 Fifth Avenue, New York

Quraish Shihab, M, Tafsir Al Misbah Jilid 10, Jakarta: Lentera Hati, 2012)

Quraish Shihab, Tafsir Al Misbah Jilid 8, (Jakarta: Lentera Hati, 2012)

Rosyidi, Suherman, Wanita Dalam Doktrin Islam, Yahudi Dan Kristen, Surabaya: Target Press

Subandy, Idi dan Bacharuddin Ali Akhmad, Komunikasi Dan Komodifikasi, Jakarta: Yayasan Pustaka Obor Indonesia, 2014

Umar, Nasaruddin, Fikih Wanita Untuk Semua, Jakarta: Serambi, 2010.

Umar, Nasarudin, Mendekati Tuban Dengan Kualitas Feminis, Jakarta: Quanta, 2014

Wadud, Amina, Quran Menurut Perempuan, Jakarta: Serambi, 2006

www.republika.co.id 